Departement für Pferde, Abteilung für Sportmedizin Pferd der Vetsuisse-Fakultät Universität Zürich

Vorsteher: Prof. Dr. med. vet. Colin Schwarzwald, PhD, Dipl. ACVIM/ECEIM Abteilungsleiter: Prof. Dr. med. vet. Michael Weishaupt, PhD, Dipl. ACVSMR

Arbeit unter wissenschaftlicher Betreuung von

Prof. Dr. med. vet. Michael Weishaupt, PhD, Dipl. ACVSMR

Dr. med. vet. Nina Waldern, $\mathrm{PhD}$

Hoof conformation in Icelandic competition horses and its interrelationship with hoof pathologies and tölt performance

Inaugural-Dissertation

zur Erlangung der Doktorwürde der

Vetsuisse-Fakultät Universität Zürich

vorgelegt von

Vanessa Herbrecht

Tierärztin

von Entlebuch, Luzern

genehmigt auf Antrag von

Prof. Dr. med. vet. Michael Weishaupt, PhD, Dipl. ACVSMR, Referent 



\section{Inhaltsverzeichnis}

Zusammenfassung in Englisch............................................ 4

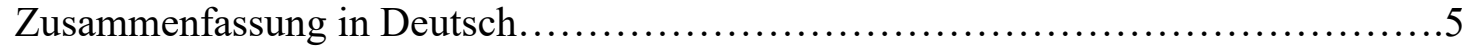

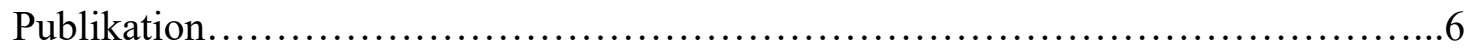

Danksagung

Lebenslauf 
Vetsuisse Faculty, University of Zurich (2021)

Vanessa Herbrecht

Equine Department, Sports Medicine Section, gschmid@vetclinics.uzh.ch

\title{
Hoof conformation in Icelandic competition horses and its interrelationship with hoof pathologies and tölt performance
}

\begin{abstract}
In order to improve four-beat-rhythm and forelimb action of tölt in Icelandic horses (ICE), special shoeing techniques are applied particularly in front hooves by increasing hoof length and height. Although regulations limit dorsal hoof wall length ( $\left.\mathrm{L}_{\mathrm{DHW}}\right)$ in competition ICE, their shoeing often deviates from a biomechanically optimal distal limb conformation. This study qualitatively and quantitatively describes current shoeing practices of ICE in competition. Moreover, the influence of $\mathrm{L}_{\mathrm{DHW}}$ on the occurrence of deviations from a standard hoof conformation, as well as on tölt performance was investigated.

At four European competition sites, hoof dimensions of 133 randomly selected ICE were measured manually, and limb conformation and hoof balance were described. Dorsopalmar/plantar and lateromedial radiographs of the left front and hind hooves were taken and various parameters related to hoof dimensions and balance were measured using the Metron-Hoof-Pro software.

Toe flares had the highest prevalence of all investigated hoof deformities. Multiple logistic regression analysis revealed that longer $\mathrm{L}_{\mathrm{DHW}}$ was associated with the occurrence of toe flares $(P=0.045)$, a broken hoof pastern axis $(P=0.003)$, and asymmetry of the quarter wall heights $(P=0.015)$. However, horses with longer $L_{D H W}$ achieved higher competition scores. In spite of its positive effect on tölt quality, a long $\mathrm{L}_{\mathrm{DHW}}$ is not recommendable as it may be associated with higher prevalence of certain hoof deformities.
\end{abstract}

Keywords: Hoof balance; Hoof dimensions; Hoof capsule deformities; Radiology; Tölt performance. 
Vetsuisse-Fakultät Universität Zürich (2021)

Vanessa Herbrecht

Departement für Pferde, Abteilung Sportmedizin, gschmid@vetclinics.uzh.ch

\section{Quantitative und qualitative Beurteilung des Beschlags und der Hufgesundheit beim} Islandpferd

\section{Zusammenfassung}

Um Viertakt und Vorhandaktion im Tölt beim Islandpferd zu verbessern, werden vor allem an den Vorderhufen spezielle Beschlagtechniken angewandt, die zu einer längeren dorsalen Hufwandlänge ( $\left.\mathrm{L}_{\mathrm{DHW}}\right)$ und hohen Hufen führen. Trotz bestehender Limitierung der $\mathrm{L}_{\mathrm{DHW}} \mathrm{im}$ Turniersport, weichen Hufbeschlag und -balance häufig von derzeit geltenden biomechanischen Prinzipien ab. Ziel der Studie war eine qualitative und quantitative Beurteilung der Beschlagsituation im Islandpferdesport, sowie die Untersuchung des Zusammenhangs zwischen LDHW und dem Auftreten von Hufkapseldeformationen. Die Gangqualität wurde anhand von Töltnoten beurteilt. Hierfür wurden an vier internationalen Turnieren stichprobenartig Hufe von 133 Islandpferden manuell vermessen, geröntgt und hinsichtlich Gliedmassenkonformation und Hufbalance beurteilt. Mit der Metron-Hoof-Pro Software wurden auf dorsopalmaren/-plantaren und lateromedialen Röntgenbildern der jeweils linken Hufe relevante Parameter für die Beschreibung von Hufdimension und -balance erfasst. Es wurden am häufigsten Flares an der Zehe beobachtet. Eine multiple Regressionanalyse zeigte, je länger die $\mathrm{L}_{\mathrm{DHW}}$, umso häufiger traten Flares im Zehenbereich $(P=.045)$, eine gebrochene Zehenachse $(P=0.003)$ und Asymmetrien der seitlichen Hufwände $(P=0.015)$ auf. Ausserdem korrelierte die $\mathrm{L}_{\mathrm{DHW}}$ positiv mit den Töltnoten. Aufgrund dieser Ergebnisse ist im Sinne des Tierschutzes für Islandpferde mit Stockmass $<1.45 \mathrm{~m}$ eine maximale $\mathrm{L}_{\mathrm{DHW}}$ von 80 bis $90 \mathrm{~mm}$ zu empfehlen.

Schlüsselwörter: Hufbalance, Hufgrösse, Hufkapseldeformation, Radiologie, Töltqualität. 


\title{
Hoof conformation in Icelandic competition horses and its interrelationship with hoof pathologies and tölt performance
}

\author{
V. Herbrecht ${ }^{a}$, N.M. Waldern ${ }^{a, *}$, S. Ellingsund Mikkelsen ${ }^{b}$, M. Kjaer $^{c}$, M.T. Dittmann ${ }^{a}$, \\ T. Wiestner ${ }^{\mathrm{a}}$, M.A. Weishaupt ${ }^{\mathrm{a}}$ \\ ${ }^{a}$ Equine Department, Vetsuisse Faculty, University of Zurich, Winterthurerstrasse 260, CH-8057 Zurich, Switzerland \\ ${ }^{\mathrm{b}}$ Vejle Hestepraksis, DK-7120 Vejle Øst, Denmark \\ c Kjær's Beslagsmedie ApS, DK-3550 Slangerup, Denmark
}

\section{A R T I C L E I N F O}

\section{Keywords:}

Hoof balance

Hoof capsule deformities

Hoof dimensions

Radiology

Tölt performance

\begin{abstract}
A B S T R A C T
In order to improve the four-beat-rhythm and forelimb action of the tölt in Icelandic horses (ICE), special shoeing techniques are applied particularly in the front hooves by increasing hoof length and height, or by adding weight to the distal limbs. Although regulations limit dorsal hoof wall length ( $\left.L_{D H W}\right)$ in competition ICE, their shoeing often deviates from a biomechanically optimal distal limb conformation. This study aimed to qualitatively and quantitatively describe current shoeing practices of ICE in competition. Moreover, the influence of $\mathrm{L}_{\mathrm{DHW}}$ on the occurrence of deviations from a standard hoof conformation, as well as on tölt performance was investigated. At four European competition sites, hoof dimensions of 133 randomly selected ICE were measured manually, and limb conformation and hoof balance were described. Dorsopalmar/-plantar and lateromedial radiographs of the left front and hind hooves were taken of each horse. Various parameters related to hoof dimensions and balance were measured on radiographs using the Metron-Hoof-Pro software.

Flares of the dorsal hoof wall had the highest prevalence of all investigated hoof deformities. Multiple logistic regression analysis revealed that longer $\mathrm{L}_{\mathrm{DHW}}$ was associated with the occurrence of toe flares $(P=$ $0.045)$, a broken hoof pastern axis $(P=0.003)$, and asymmetry of the quarter wall heights $(P=0.015)$. However, horses with a longer $\mathrm{L}_{\mathrm{DHW}}$ achieved higher scores in competition. In spite of its positive effect on tölt performance, a long $\mathrm{L}_{\mathrm{DHW}}$ is not recommendable as it may be associated with a higher prevalence of certain hoof deformities.
\end{abstract}

2020 Elsevier Ltd. All rights reserved.

\section{Introduction}

In Icelandic horses (ICE), shoeing has been traditionally used to influence the gait. Front hooves are grown high and long and additional weights are added. This method has empirically been associated with enhanced performance in competition (Feldmann and Rostock, 1986). Scientific studies recently confirmed that such shoeing styles lead to an improvement of tölt quality by increasing regularity of its four beat rhythm, lowering stride frequency, and enhancing forelimb action (Pecha et al., 2011; Waldern et al., 2013; Weishaupt et al., 2013).

In spite of this improvement of performance, this shoeing style may be problematic from a biomechanical perspective as it contradicts standard principles of balancing hooves. A longer toe results in a longer lever arm during break-over, prolongs its duration

\footnotetext{
* Corresponding author.

E-mail address: nwaldern@vetclinics.uzh.ch (N.M. Waldern).
}

and increases the distal interphalangeal joint (DIPJ) moment in both ICE (Weishaupt et al., 2014) and Warmblood horses (WB) (Clayton, 1990). The higher DIPJ moment during break-over increases tension within the deep digital flexor tendon (DDFT) and its accessory ligament, and compression of the navicular bone (O'Grady and Poupard, 2003; Page and Hagen, 2002). A long toe has also been associated with the development of horn capsule deformities such as hoof cracks and flaring (Moyer, 2003).

In order to prevent extremes, the International Federation of Icelandic Horse Associations (FEIF) introduced shoe checking procedures at competitions. When the present study was carried out, the permitted front dorsal hoof wall length $\left(\mathrm{L}_{\mathrm{DHW}}\right)$ for ICE in competition was $95 \mathrm{~mm}$ for horses up to $1.44 \mathrm{~m}$ withers height and $100 \mathrm{~mm}$ for horses of $1.45 \mathrm{~m}$ and taller (International Federation of Icelandic Horse Associations, 2013). To the authors' knowledge, there are no published studies determining whether controlled hoof size in competition conforms to current shoeing standards, or if a high, long hoof conformation is associated with structural deformities of the hoof capsule. 
In domestic horses, hoof shape and health is significantly determined by hoof care, i.e. trimming and/or shoeing. The aim of regular shortening and reshaping the hoof is to restore hoof balance and, presumably, optimise limb loading. In WB, hoof trimming has been shown to have a crucial influence on hoof conformation: Shortening $\mathrm{L}_{\mathrm{DHW}}$ influences the position of the distal phalanx (P3) in relation to the hoof capsule, and increases dorsal hoof $\left(\mathrm{A}_{\mathrm{DHW}}\right)$ and palmar/plantar P3 angles (A $\mathrm{P}$ 3palmar

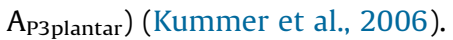

Correct hoof preparation and shoeing involves consideration of aspects including hoof angle and length, alignment of the hoofpastern axis (HPA), as well as longitudinal and mediolateral hoof balance (Balch et al., 1991). Standardised radiographs provide valuable information for a complete evaluation including alignment of bony structures within the hoof capsule (Kummer et al., 2004). Beside these general guidelines, anatomical parameters such as body mass (BM) (Balch et al., 1995; Turner, 1992) and size (Kummer et al., 2006; Thieme et al., 2015) of the horse, as well as limb conformation (O'Grady and Castelijns, 2011) and the size of P3 (Kolstrung et al., 2004) should also be considered when assessing shape and size of the individual hoof.

The aims of this study were: (1) to quantitatively and qualitatively assess current shoeing practices, hoof condition and balance in ICE at different international competition sites by means of manual and radiographic measurements; (2) to investigate the correlation between $\mathrm{L}_{\mathrm{DHW}}$ and the occurrence of hoof deformities; and (3) to correlate tölt scores in competition with $\mathrm{L}_{\text {DHW. }}$.

It was hypothesised that ICE with high, long hooves would show more deviations in standard hoof conformation and higher tölt scores.

\section{Materials and methods}

Experimental design

In total, 133 horses (withers height, $1.39 \pm 0.03$ m [mean \pm SD]; BM: $368 \pm 29$ $\mathrm{kg}$ ) were drawn by lot (using the start number) by the organisers at four international FEIF competitions: International FEIF Breeding Show in Herning, Denmark (DEN, $n=30$ ), National Icelandic Horse Competition (Landsmòt) in Reykjavík, Iceland (ISL, $n=33$ ), Nordic Championship in Eskilstuna, Sweden (SWE, $n$ $=33$ ) and Mid-European Championship in Wehrheim, Germany (GER, $n=37$ ). Shoeing condition, hoof and limb conformation were assessed by a veterinarian (M. A.W.) and an experienced farrier for ICE (M.K.) following a standardised protocol (Table 1). Radiographs of the left front (LF) and hind (LH) hoof were taken.

\section{Table 1}

Frequencies of shoeing characteristics and limb conformations (mean \pm standard deviation or prevalence in absolute numbers and percentages; total $n=133$ ). Parameters were recorded if the condition was observed in one or both limbs of the respective limb or hoof pair.

\begin{tabular}{lll}
\hline Shoeing & Front limb & Hind limb \\
\hline Horseshoe width (left hooves; mm) & $122 \pm 5$ & $111 \pm 5$ \\
Pads & $68(51 \%)$ & $1(1 \%)$ \\
Packing material & $56(42 \%)$ & $1(1 \%)$ \\
Limb and hoof conformation & & \\
Hoof shape asymmetry & $39(38 \%)$ & $6(9 \%)$ \\
Toe-in & $17(12 \%)$ & $0(0 \%)$ \\
Toe-out & $119(84 \%)$ & $123(92 \%)$ \\
Base-narrow & $22(16 \%)$ & $12(9 \%)$ \\
Base-wide & $9(7 \%)$ & $5(4 \%)$ \\
Short, upright pastern & $49(37 \%)$ & $77(58 \%)$ \\
Long, sloping pastern & $1(1 \%)$ & $0(0 \%)$ \\
Knock-kneed & $92(69 \%)$ & - \\
Bow-legged & $0(0 \%)$ & - \\
Over at the knee & $1(1 \%)$ & - \\
Back at the knee & $9(7 \%)$ & - \\
Camped-out & $1(1 \%)$ & $12(9 \%)$ \\
Camped-under & $32(24 \%)$ & $2(1 \%)$ \\
Cow-hocked & - & $101(76 \%)$ \\
Sickle-hocked & - & $3(2 \%)$ \\
\hline
\end{tabular}

Data acquisition

Withers height was determined using a measuring stick with horses standing square on level ground. Body mass was assessed using a weight tape (Equimax, Virbac, Barneveld). Dorsal hoof wall length and $A_{D H W}$ were measured according to Weishaupt et al. (2013). Hoof capsule deformities and pathologies were recorded and included: Asymmetry of quarter wall heights (lateral/medial), occurrence of flares (toe/lateral/ medial wall), uneven coronary band (deviations of the outline of the coronary band), ring hooves, contracted heels, uneven bulbs and hoof cracks. Hoof balance was evaluated and whether hooves were in need of trimming or shoeing.

Size-standardised radiographs were taken according to Kummer et al. (2004) in lateromedial and dorsopalmar/dorsoplantar projections, using a digital X-ray system and cassettes of Sound Eklin (Sound-Eklin Wireless Mark 1114cw/Mark IIIG). Fifty millimetre metal markers and landmarks with barium dots were placed on the hoof as described by Kummer et al. (2004). For reasons of practicality, radiographs were only taken of the LF and LH.

Radiographic measurements were done after importing the radiographs into Metron-Hoof-Pro (EponaMind). Scaling was checked using the markers placed on the dorsal hoof wall in lateromedial images and the calibration marker embedded into the podoblock in dorsopalmar/dorsoplantar projections. The ground reference line defined the ventral margin of the shoe; protruding nails, road nails or studs were neglected. Ten parameters in lateromedial views (Fig. 1) and four parameters in dorsopalmar/dorsoplantar views (Fig. 2) were measured. Cranial balance length ( $\mathrm{L}_{\text {Balance }}$ ) was calculated by dividing $\mathrm{L}_{\text {Support_Toe }}$ by the supporting length of the horseshoe $L_{\text {Support }}:\left(L_{\text {Balance }}=\frac{L_{\text {Support Toe }}}{L_{\text {Support }}}\right)$. To relate dimensions of the hoof capsule to a fix bony structure, the ratio $\left(\mathrm{R}_{\mathrm{Volc}}=\frac{\mathrm{V}_{\text {olcHoof }}}{\mathrm{V}_{\text {olcP3 }}}\right)$ of the volume coefficients of the hoof capsule without shoe $\left(\right.$ Volc $_{\text {Hoof }}=\mathrm{L}_{\mathrm{Hoof}}$ (length) $\times \mathrm{W}_{\mathrm{Hoof}}$ (width) $\times \mathrm{H}_{\text {Hoof }}$ (height of the hoof capsule)) and $\mathrm{P} 3$ (Volc V $33=\mathrm{L}_{\mathrm{P} 3}$ (length) $\times \mathrm{W}_{\mathrm{P} 3}$ (width) $\times \mathrm{H}_{\mathrm{P} 3}$ (height of P3)) was calculated. The $A_{P 3 p a l m a r} / A_{P 3 p l a n t a r}$ on the lateromedial view was defined as positive if the apex of P3 was lower relative to its wings and as negative if the apex was higher than the wings (Fig. 1). On the dorsopalmar/ dorsoplantar view, the mediolateral angle of P3 to the ground ( $\left.A_{P 3 m e d-l a t}\right)$ was defined as positive if the lateral wing of P3 was higher than the medial one, and vice versa (Fig. 2).

\section{Gait performance}

The correlation between tölt performance and $\mathrm{L}_{\mathrm{DHW}}$ was tested using the scores of the qualification and final runs of 50 horses competing in four gait or tölt competitions (International Federation of Icelandic Horse Associations, 2013) in SWE and GER.

\section{Statistical method}

Statistical analysis was performed with SigmaStat (version 3.5, Systat) and $\mathrm{R}$ Studio (version 3.4.4). Normality of data was tested prior to further analyses (Kolmogorov-Smirnov test). Data determined from the horses at the four competition sites were compared using one-way ANOVA with succeeding posthoc t-tests (Holm-Sidak method). Differences between front and hind limbs were tested with $t$ tests. To test for an association between $\mathrm{L}_{\mathrm{DHW}}$ or $\mathrm{R}_{\mathrm{Volc}}$, and selected continuous hoof parameters and gait performance, we applied the function cor.test, with the test statistic based on the Pearson's product moment correlation coefficient. To test if hoof pathologies were dependent on hoof size, several independent logistic regression models were applied, using $\mathrm{L}_{\mathrm{DHW}}$ or $\mathrm{R}_{\mathrm{Volc}}$ as a predicting value and the presence or absence of the pathology as a binary outcome variable. Level of significance was set at $P<0.05$.

\section{Ethical review}

Experiments were carried out with the approval of the Animal Health and Welfare Commission of the Canton of Zurich (Approval number, 206/2010; Approval date, 9 November 2010).

\section{Results}

\section{Descriptive data}

Based on the assessment of farrier and veterinarian, $72 \%$ of the investigated horses were in need to be shod. Results regarding shoeing characteristics and limb conformation are listed in Table 1. The most frequent conformation was toed-out in combination with knock knees in front and a cow-hocked conformation in hind limbs.

Manually and radiographically determined hoof dimensions and angles at the four different competition sites are compared in Table 2. Body mass and $\mathrm{L}_{\mathrm{DHW}}$ were significantly increased at ISL. Dorsal hoof length showed a (weak) significant relationship with 


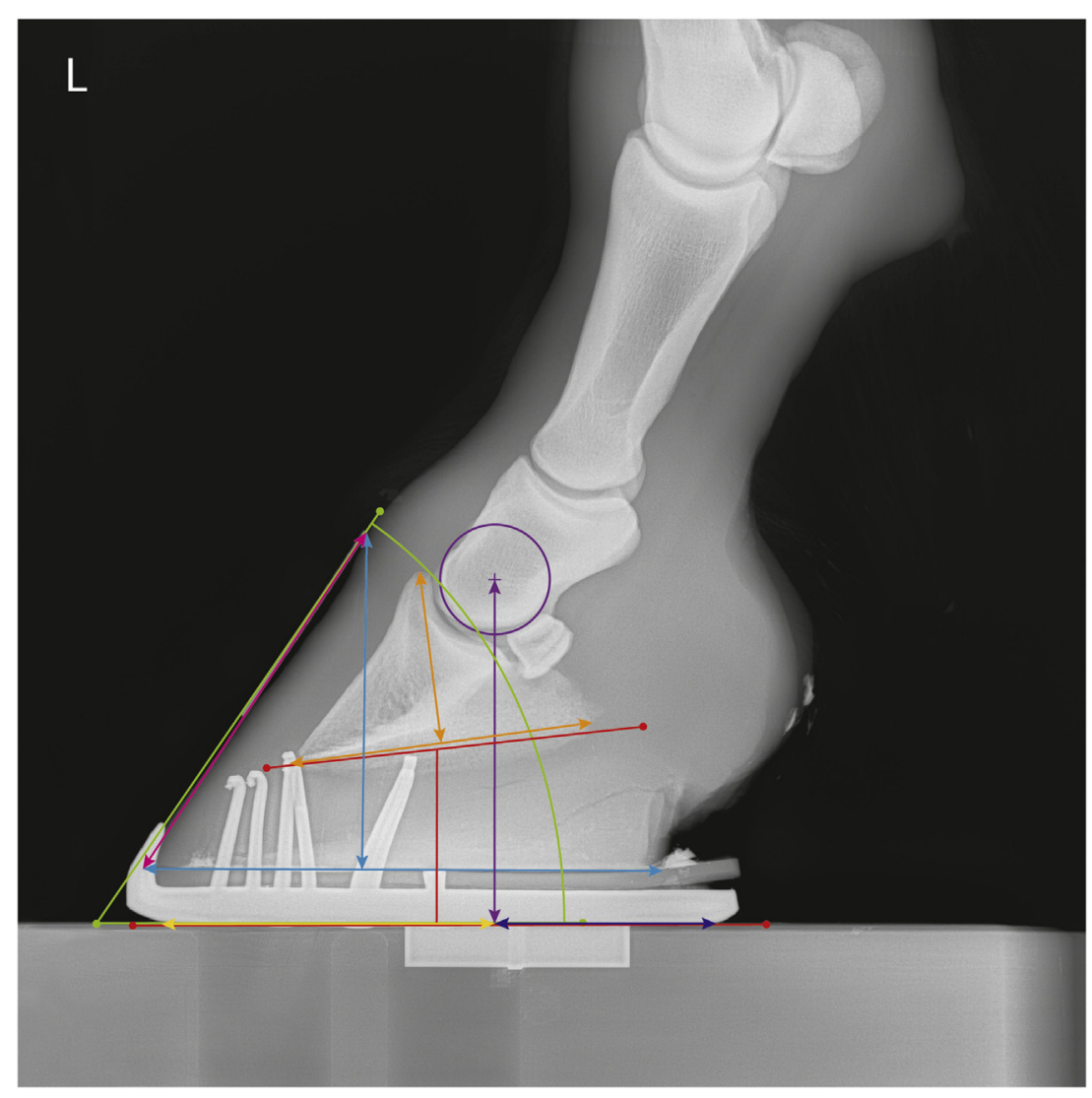

Fig. 1. Lengths.

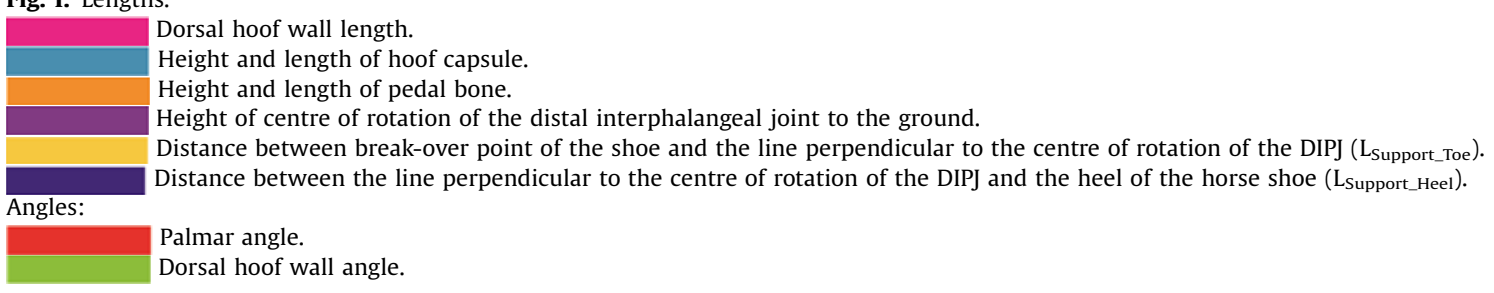

withers height $\left(r^{2}=0.04 ; P=0.02\right)$, but not with BM $\left(r^{2}=0.01 ; P=\right.$ 0.37). Furthermore, $\mathrm{L}_{\mathrm{DHW}}$ was correlated with $\mathrm{L}_{\text {Support_Toe }}\left(\mathrm{LF}: r^{2}=\right.$ 0.46; $P<0.01$; LH: $\left.r^{2}=0.34 ; P<0.01\right)$.

The mean of $A_{P 3 \text { palmar }} / A_{P 3 p l a n t a r}$ was $4^{\circ} ; 5 \%$ of the horses had a negative $A_{P 3 p a l m a r}\left(-0.5 \pm 0.3^{\circ}\right)$ and $13 \%$ a negative $A_{P 3 \text { plantar }}(-1.6$ $\left.\pm 1.4^{\circ}\right)$. In $95 \%$ of the $\mathrm{LF}$ and $86 \%$ of the $\mathrm{LH}, \mathrm{A}_{\mathrm{P} 3 \mathrm{med}-\mathrm{lat}}$ was positive (lateral higher than medial). Only one horse in the LF and two horses in the $\mathrm{LH}$ had an $\mathrm{A}_{\mathrm{P} 3 m e d-l a t}$ of $0^{\circ}$. Both in LF and in $\mathrm{LH}$, $A_{H W \_m e d}$ was steeper than $A_{H W \_l a t}$

Prevalence of hoof capsule deformities and association with $L_{D H W}$

The prevalence of different hoof capsule deformities and deviations of the HPA is presented in Table 3. The most frequently detected deformity was flares and the HPA was mostly broken backwards, especially in the front limbs. In the LF, the occurrence of flares at the toe $(P=0.042)$, a broken HPA $(P=0.003)$, and different heights of the quarter walls $(P=0.013)$ were positively associated with $\mathrm{L}_{\mathrm{DHW}}$. The occurrence of flares $(P=0.051)$ and a broken HPA $(P$ $=0.009$ ) were positively associated with $R_{\text {Volc }}$.

\section{Association of $L_{D H W}$, resp. $R_{\text {Volc }}$ with gait performance}

There was a positive correlation between $\mathrm{L}_{\mathrm{DHW}}\left(r^{2}=0.35 ; P<\right.$ 0.01 ; Fig. 3$)$ and $\mathrm{R}_{\mathrm{Volc}}\left(r^{2}=0.24 ; P<0.001\right.$; Fig. 4$)$ with tölt scores, indicating that horses with longer hooves generally received higher marks in competition.

\section{Discussion}

As hind hooves were not specifically trimmed for competition, the discussion will focus on data from the front hooves.

When compared to data from horses with similar withers height or $\mathrm{BM}, \mathrm{L}_{\mathrm{DHW}}$ of the study horses $(89 \pm 7 \mathrm{~mm})$ was longer than in ICE with a standard shoeing (Waldern et al., 2020) or threegaited horses and ponies (Turner, 1992; Thieme et al., 2015). Front hoof $\mathrm{L}_{\mathrm{DHw}}$ measured in ISL was significantly longer $(94 \pm 6 \mathrm{~mm}$ ) compared to all other competition sites $(88 \pm 6 \mathrm{~mm})$ and almost as long as in ICE with an extreme competition shoeing (96.1 \pm 3.1 $\mathrm{mm}$ ); all horses selected for an $\mathrm{L}_{\mathrm{DHW}}$ close to the maximal length permitted by the FEIF (Waldern et al., 2020). This might reflect a more traditional way of shoeing competition horses in Iceland. Conversely, at the other competition sites, there might be a stronger awareness for the common conventions of a standard shoeing in other horse breeds focusing on biomechanical principles assumed to be beneficial for the orthopaedic health of the distal limb (Kummer et al., 2006). Dorsal hoof length was found to be correlated to withers height (Kummer et al., 2006; Thieme et al., 2015; Waldern et al., 2020) and relatively longer in ponies compared to WB (Thieme et al., 2015). The correlation in 


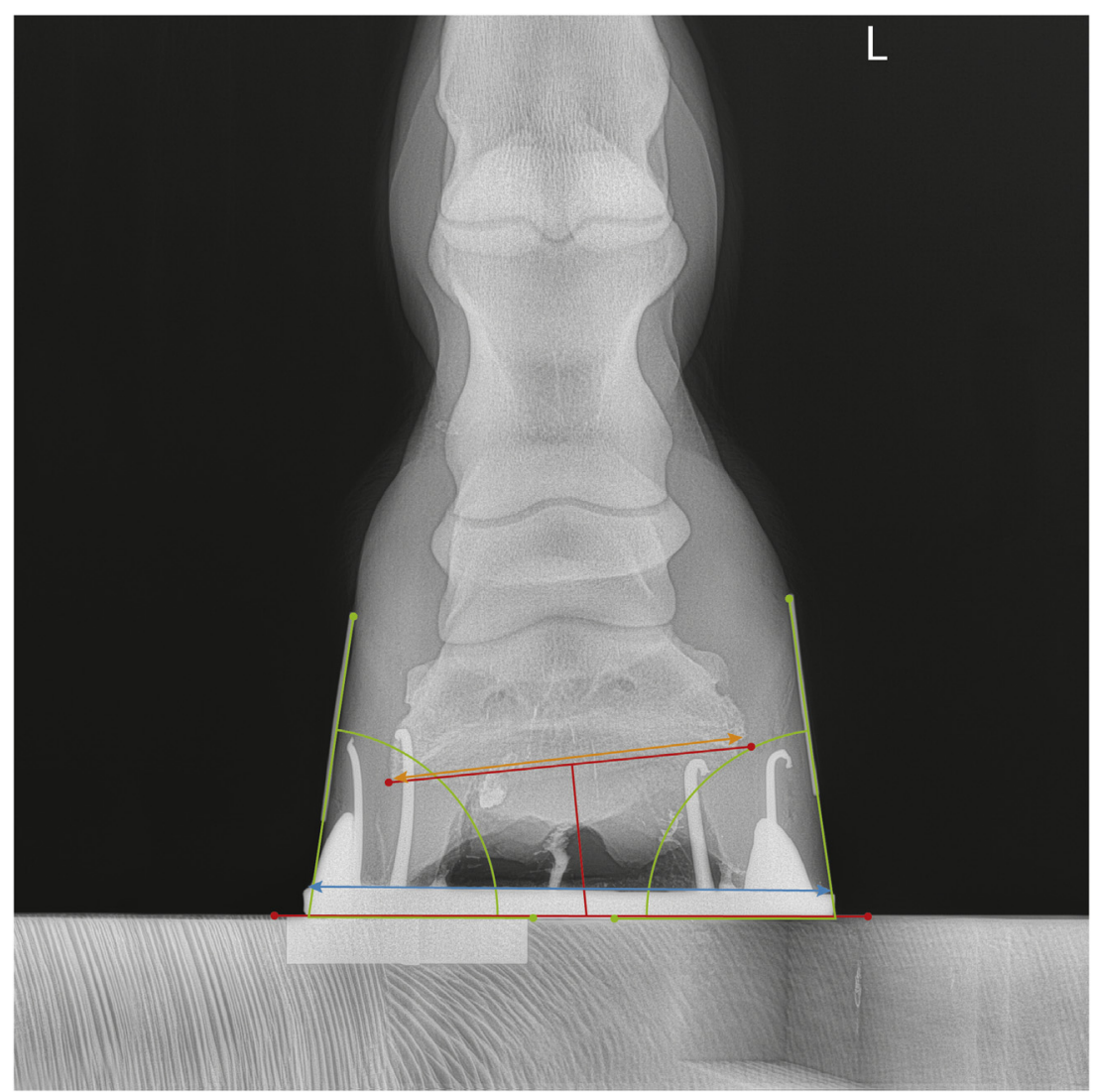

Fig. 2. Lengths

$\begin{array}{ll} & \text { Width of pedal bone. } \\ \text { Width of hoof capsule. } & \\ \text { Angles: } & \text { Medio-lateral angle. } \\ & \text { Lateral/medial side wall angle. }\end{array}$

our study was only weak probably due to the small range in withers height. Compared to Waldern et al. (2020), $\mathrm{R}_{\text {Volc }}$ in LF (4.8 \pm 0.6 ) was almost as large as in ICE with extreme competition shoeing $(5.1 \pm 0.4)$ and larger than in normally shod ICE or WB at the end of the shoeing period (both $4.1 \pm 0.4$ ).

In a well-balanced WB hoof, $\mathrm{L}_{\text {Balance }}$ should be about $50 \%$ (O'Grady and Poupard, 2003). In the studied ICE, L $\mathrm{L}_{\text {Balance (LF: } 64 \pm}$ $4 \%$; $\mathrm{LH}: 62 \pm 5 \%$ ) was clearly longer than this recommendation and in LF it was also longer than in normally shod ICE (LF: $59.1 \pm 2.5$; LH: $61.0 \pm 3.3$; Waldern et al., 2020) and three-gaited ponies (LF: $61 \pm 4 \%$; LH: $63 \pm 4 \%$; Thieme et al., 2015). Similar to ICE with an extreme competition shoeing (Waldern et al., 2020), L Lalance was larger in LF than in LH, contrasting findings in normally shod ICE, WB horses (Waldern et al., 2020) and three-gaited ponies (Thieme et al., 2015).

In our study, $\mathrm{L}_{\mathrm{DHW}}$ positively correlated with $\mathrm{L}_{\text {Support_Toe, but not }}$

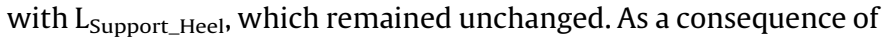
the force distribution within the hoof, $\mathrm{L}_{\text {Support_Toe }}$ is less prone to wear and grows more than $\mathrm{L}_{\text {Support_Heel }}$ (Back and Pille, 2013; Barrey, 1990). Thus, $\mathrm{L}_{\mathrm{DHW}}$, which is easy to assess in practice, may also provide information about longitudinal hoof balance.

In the studied ICE, the HPA was most often broken backwards and was associated with a long $\mathrm{L}_{\mathrm{DHW}}$. However, mean $\mathrm{A}_{\mathrm{DHW}}$ of the study horses was in accordance with reference values published by


ing literature data (O'Grady and Poupard, 2003; Wissdorf et al., 2010), $A_{\text {DHW }}$ was even slightly steeper in LF compared to LH. The broken backwards HPA therefore might also result from the frequently observed short, upright LF pastern conformation.

In the literature, indications for $A_{P 3 p a l m a r} / A_{P 3 p l a n t a r}$ vary between $0-8^{\circ}$ (Redden, 2003), $2-10^{\circ}$ (Parks, 2003) and 3-10 (Butler et al., 2008). In the current study, the mean AP3palmar/ $A_{P 3 p l a n t a r}$ was rather small $\left(4 \pm 3^{\circ}\right)$. A low $\left(<3^{\circ}: 39 \%\right)$ or negative (5\%) $A_{\text {P3palmar }} / A_{P 3 p l a n t a r}$ and a backwards broken HPA are biomechanically problematic, as during limb loading and especially during break-over, structures like the DDFT and the navicular bone will be subjected to increased forces (Eliashar et al., 2004; Floyd and Mansmann, 2007).

Side wall angles of the hooves have been measured by Wissdorf et al. (2010) and Thieme et al. (2015) with $A_{H W \_m e d}\left(82 \pm 3^{\circ}\right.$, resp. $\left.81 \pm 5^{\circ}\right)$ being steeper compared to $A_{H W \_l a t}\left(75 \pm 3^{\circ}\right.$, resp. $\left.78 \pm 4^{\circ}\right)$. In the present study, a similar side wall conformation was observed

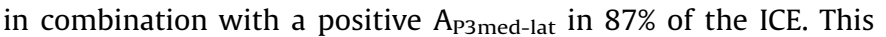
mediolateral imbalance may be associated with the toed-out conformation which was found in most of the horses (LF: 84\%; LH: $92 \%)$. As horses with this conformation are likely to put more weight on the medial wall of the hoof, the resulting pressure in this area could impair hoof growth, resulting in this mediolateral imbalance.

Deviations from normal hoof/limb conformation and balance, shoeing type, as well as hoof growth during the shoeing period are known to affect forces applied on the internal structures of the equine foot (Willemen et al., 1999; Eliashar et al., 2004; Moleman et al., 2006) and have been related to various hoof pathologies 
Table 2

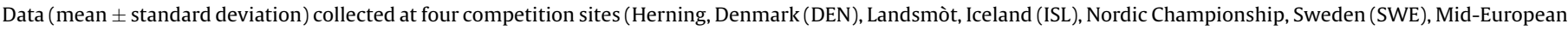
Championship, Germany (GER).

\begin{tabular}{|c|c|c|c|c|c|}
\hline & Total & DEN & ISL & SWE & GER \\
\hline Number of horses & 133 & 30 & 33 & 33 & 37 \\
\hline Withers height $(\mathrm{cm})$ & $139 \pm 3$ & $139 \pm 3$ & $140 \pm 4$ & $139 \pm 3$ & $139 \pm 3$ \\
\hline $\mathrm{BM}(\mathrm{kg})$ & $369 \pm 31$ & $363 \pm 34^{b}$ & $382 \pm 31^{a}$ & $359 \pm 25^{b}$ & $372 \pm 30$ \\
\hline \multicolumn{6}{|l|}{ Front left } \\
\hline $\mathrm{L}_{\mathrm{DHW}}{ }^{\mathrm{c}}(\mathrm{mm})$ & $89 \pm 7$ & $89 \pm 6^{b}$ & $94 \pm 6^{a}$ & $88 \pm 6^{b}$ & $87 \pm 6^{b}$ \\
\hline $\mathrm{L}_{\mathrm{DHW}}(\mathrm{mm})$ & $87 \pm 6$ & $86 \pm 7^{b}$ & $90 \pm 6^{a}$ & $86 \pm 6^{b}$ & $85 \pm 6^{b}$ \\
\hline $\mathrm{A}_{\mathrm{DHW}}{ }^{\mathrm{c}}$ (degree) & $51 \pm 4$ & $51 \pm 3$ & $51 \pm 3$ & $51 \pm 3$ & $52 \pm 4$ \\
\hline $\mathrm{A}_{\mathrm{DHW}}$ (degree) & $53 \pm 3$ & $54 \pm 3$ & $54 \pm 3$ & $53 \pm 4$ & $52 \pm 3$ \\
\hline $\mathrm{H}_{\text {Hoof }}(\mathrm{mm})$ & $70 \pm 5$ & $70 \pm 6$ & $72 \pm 5$ & $70 \pm 5$ & $68 \pm 5$ \\
\hline $\mathrm{L}_{\text {Hoof }}(\mathrm{mm})$ & $118 \pm 6$ & $116 \pm 6$ & $117 \pm 6$ & $118 \pm 5$ & $119 \pm 6$ \\
\hline $\mathrm{W}_{\text {Hoof }}(\mathrm{mm})$ & $120 \pm 6$ & $118 \pm 4$ & $122 \pm 6$ & $118 \pm 6$ & $120 \pm 6$ \\
\hline $\mathrm{H}_{\mathrm{P} 3}(\mathrm{~mm})$ & $39 \pm 2$ & $39 \pm 2$ & $39 \pm 3$ & $39 \pm 2$ & $39 \pm 2$ \\
\hline $\mathrm{L}_{\mathrm{P} 3}(\mathrm{~mm})$ & $69 \pm 4$ & $68 \pm 3$ & $69 \pm 4$ & $70 \pm 4$ & $70 \pm 4$ \\
\hline $\mathrm{W}_{\mathrm{P} 3}(\mathrm{~mm})$ & $77 \pm 4$ & $76 \pm 3$ & $78 \pm 5$ & $77 \pm 4$ & $77 \pm 4$ \\
\hline $\mathrm{R}_{\text {Volc }}$ & $4.8 \pm 0.6$ & $4.7 \pm 0.6$ & $5.0 \pm 0.6$ & $4.7 \pm 0.7$ & $4.7 \pm 0.5$ \\
\hline A $_{\text {P3palmar }}$ (degree) & $4 \pm 3$ & $4 \pm 2$ & $5 \pm 3$ & $4 \pm 3$ & $4 \pm 3$ \\
\hline $\mathrm{A}_{\mathrm{P} 3 \mathrm{med}-\mathrm{lat}}$ (degree) & $2 \pm 1$ & $2 \pm 1$ & $2 \pm 1$ & $1 \pm 1$ & $2 \pm 1$ \\
\hline $\mathrm{A}_{\mathrm{HW} \_ \text {med }}$ (degree) & $77 \pm 4$ & $78 \pm 3$ & $76 \pm 4$ & $79 \pm 4$ & $76 \pm 4$ \\
\hline $\mathrm{A}_{\mathrm{HW} \_l a t}$ (degree) & $74 \pm 4$ & $74 \pm 3$ & $73 \pm 3$ & $76 \pm 4$ & $74 \pm 4$ \\
\hline $\mathrm{L}_{\text {Balance }}(\%)$ & $64 \pm 4$ & $62 \pm 4$ & $66 \pm 4$ & $64 \pm 4$ & $63 \pm 3$ \\
\hline \multicolumn{6}{|l|}{ Hind left } \\
\hline $\mathrm{L}_{\mathrm{DHW}}{ }^{\mathrm{c}}(\mathrm{mm})$ & $86 \pm 6$ & $84 \pm 4^{b}$ & $89 \pm 6^{a}$ & $84 \pm 5^{b}$ & $85 \pm 5^{b}$ \\
\hline $\mathrm{L}_{\mathrm{DHW}}(\mathrm{mm})$ & $83 \pm 6$ & $81 \pm 5^{b}$ & $86 \pm 6^{a}$ & $81 \pm 5^{b}$ & $83 \pm 5^{b}$ \\
\hline $\mathrm{A}_{\mathrm{DHW}}{ }^{\mathrm{c}}$ (degree) & $52 \pm 4$ & $52 \pm 5$ & $51 \pm 4$ & $52 \pm 4$ & $53 \pm 4$ \\
\hline $\mathrm{A}_{\mathrm{DHW}}$ (degree) & $52 \pm 4$ & $53 \pm 4$ & $52 \pm 4$ & $53 \pm 4$ & $51 \pm 3$ \\
\hline $\mathrm{L}_{\text {Hoof }}(\mathrm{mm})$ & $114 \pm 8$ & $114 \pm 15$ & $112 \pm 4$ & $113 \pm 4$ & $116 \pm 6$ \\
\hline $\mathrm{W}_{\text {Hoof }}(\mathrm{mm})$ & $108 \pm 6$ & $107 \pm 4$ & $109 \pm 6$ & $107 \pm 7$ & $108 \pm 6$ \\
\hline $\mathrm{H}_{\text {Hoof }}(\mathrm{mm})$ & $69 \pm 4$ & $68 \pm 4$ & $71 \pm 4$ & $68 \pm 4$ & $69 \pm 4$ \\
\hline $\mathrm{L}_{\mathrm{P} 3}(\mathrm{~mm})$ & $65 \pm 4$ & $64 \pm 3$ & $66 \pm 4$ & $67 \pm 4$ & $66 \pm 3$ \\
\hline $\mathrm{W}_{\mathrm{P} 3}(\mathrm{~mm})$ & $73 \pm 3$ & $72 \pm 3$ & $73 \pm 4$ & $73 \pm 3$ & $74 \pm 3$ \\
\hline $\mathrm{H}_{\mathrm{P} 3}(\mathrm{~mm})$ & $40 \pm 3$ & $39 \pm 2$ & $40 \pm 5$ & $39 \pm 2$ & $40 \pm 2$ \\
\hline $\mathrm{R}_{\text {Volc }}$ & $4.5 \pm 0.6$ & $4.6 \pm 0.8$ & $4.5 \pm 0.6$ & $4.3 \pm 0.5$ & $4.5 \pm 0.4$ \\
\hline $\mathrm{A}_{\mathrm{P} 3 \text { plantar }}$ (degree) & $4 \pm 7$ & $3 \pm 3$ & $4 \pm 5$ & $5 \pm 12$ & $3 \pm 3$ \\
\hline$A_{\text {P3med-lat }}$ (degree) & $2 \pm 1$ & $2 \pm 1$ & $2 \pm 1$ & $2 \pm 1$ & $1 \pm 1$ \\
\hline$A_{H W \_m e d}$ (degree) & $81 \pm 4$ & $81 \pm 3$ & $81 \pm 8$ & $82 \pm 4$ & $80 \pm 4$ \\
\hline$A_{H W \_l a t}$ (degree) & $76 \pm 4$ & $76 \pm 4$ & $74 \pm 4$ & $76 \pm 3$ & $78 \pm 5$ \\
\hline $\mathrm{L}_{\text {Balance }}(\%)$ & $62 \pm 4$ & $62 \pm 4$ & $64 \pm 5$ & $62 \pm 3$ & $61 \pm 5$ \\
\hline
\end{tabular}

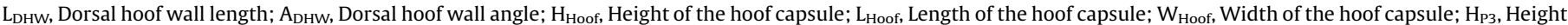

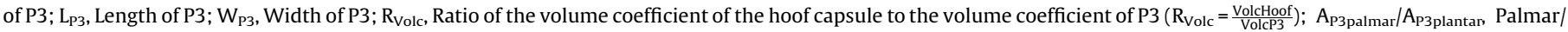

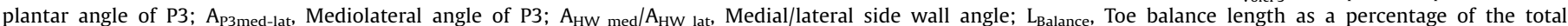
supporting length of the horseshoe ( $L_{\text {Balance }}=\frac{\text { LSupportToe }}{\text { LSupport }}$ ).

a,b $P<0.05$ between the four competition sites.

${ }^{\mathrm{c}}$ Manually measured hoof parameters.

Table 3

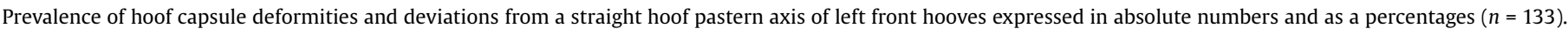

\begin{tabular}{|c|c|c|c|c|c|c|c|}
\hline \multirow[t]{3}{*}{ Hoof capsule deformities } & \multirow{3}{*}{ All horses } & \multicolumn{5}{|c|}{ Prevalence front hooves } & \multirow{3}{*}{$\begin{array}{l}\text { Prevalence } \\
\text { hind hooves }\end{array}$} \\
\hline & & \multicolumn{4}{|c|}{ Horses with $\mathrm{L}_{\mathrm{DHW}}(\mathrm{mm})$} & \multirow[t]{2}{*}{$P$ of $\mathrm{L}_{\mathrm{DHW}}$} & \\
\hline & & $\begin{array}{l}<85 \\
(n=35)\end{array}$ & $\begin{array}{l}85-90( \\
n=40)\end{array}$ & $\begin{array}{l}90-95 \\
(n=30)\end{array}$ & $\begin{array}{l}>95 \\
(n=28)\end{array}$ & & \\
\hline Contracted heels & $7(5 \%)$ & $6 \%$ & $5 \%$ & $3 \%$ & $7 \%$ & 0.86 & $4(3 \%)$ \\
\hline Different heights of quarter walls & $82(62 \%)$ & $40 \%$ & $60 \%$ & $70 \%$ & $82 \%$ & 0.013 & $83(62 \%)$ \\
\hline Uneven bulbs & $26(20 \%)$ & $20 \%$ & $20 \%$ & $17 \%$ & $21 \%$ & 0.93 & $10(8 \%)$ \\
\hline Uneven coronary band & $32(24 \%)$ & $26 \%$ & $18 \%$ & $27 \%$ & $29 \%$ & 0.67 & $22(17 \%)$ \\
\hline Flares toe & $106(80 \%)$ & $71 \%$ & $80 \%$ & $77 \%$ & $93 \%$ & 0.042 & $58(44 \%)$ \\
\hline Flares lateral & $95(71 \%)$ & $71 \%$ & $65 \%$ & $63 \%$ & $89 \%$ & 0.22 & $81(61 \%)$ \\
\hline Flares medial & $103(77 \%)$ & $77 \%$ & $78 \%$ & $73 \%$ & $82 \%$ & 0.87 & $49(37 \%)$ \\
\hline Flares (all) & 117 (88\%) & $83 \%$ & $88 \%$ & $87 \%$ & $96 \%$ & 0.060 & $101(76 \%)$ \\
\hline Hoof cracks & $23(17 \%)$ & $17 \%$ & $18 \%$ & $23 \%$ & $11 \%$ & 0.79 & $9(7 \%)$ \\
\hline Ring hooves & 37 (28\%) & $23 \%$ & $23 \%$ & $40 \%$ & $29 \%$ & 0.16 & $22(17 \%)$ \\
\hline Hoof pastern axis & & & & & & 0.003 & \\
\hline Forward broken & $15(11 \%)$ & $14 \%$ & $13 \%$ & $13 \%$ & $4 \%$ & & $37(28 \%)$ \\
\hline Backward broken & 89 (67\%) & $49 \%$ & $68 \%$ & $63 \%$ & $93 \%$ & & $50(38 \%)$ \\
\hline
\end{tabular}

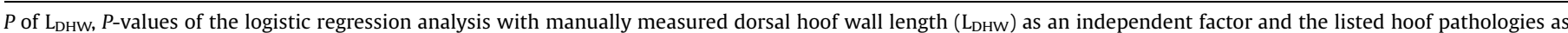
dependent factor. 


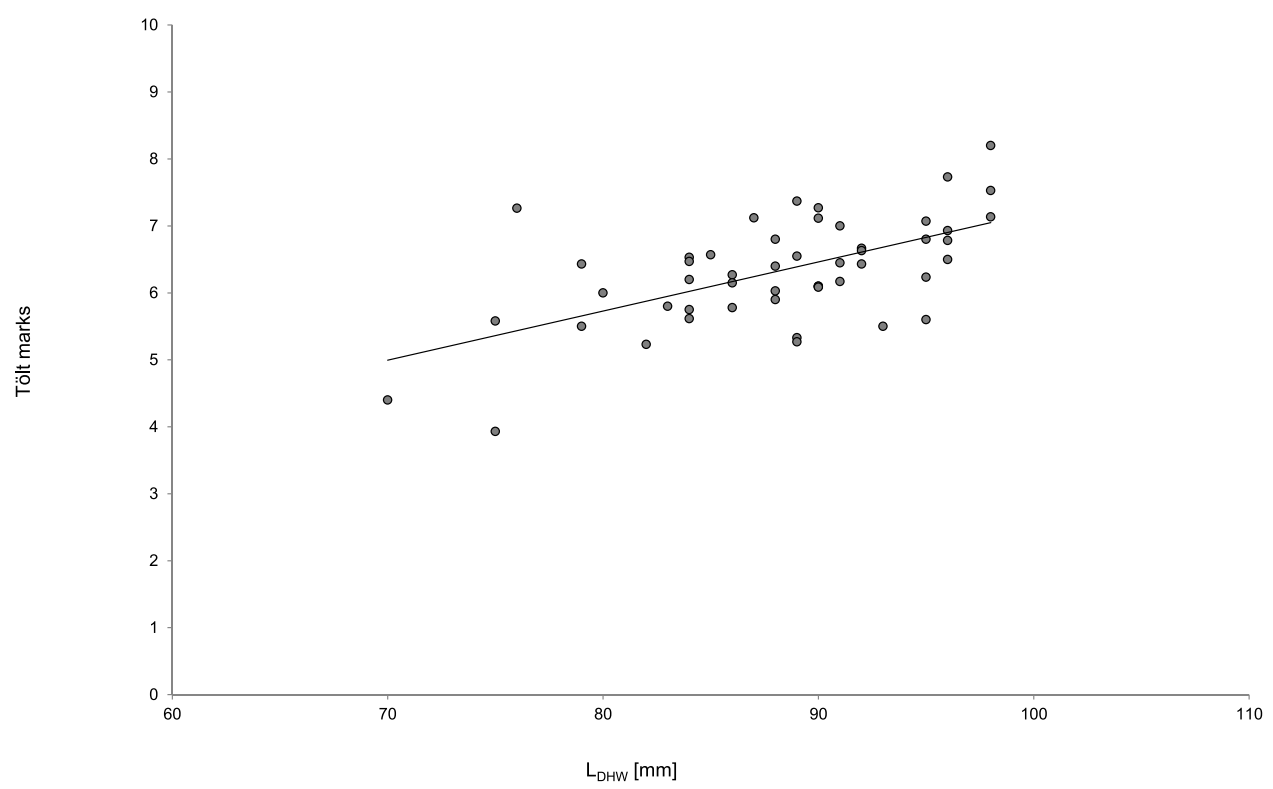

Fig. 3. Correlations of tölt marks with dorsal hoof wall length ( $\left.L_{\mathrm{DHW}}\right)$ of the left front hoof $\left(n=50 ; r^{2}=0.35\right)$.

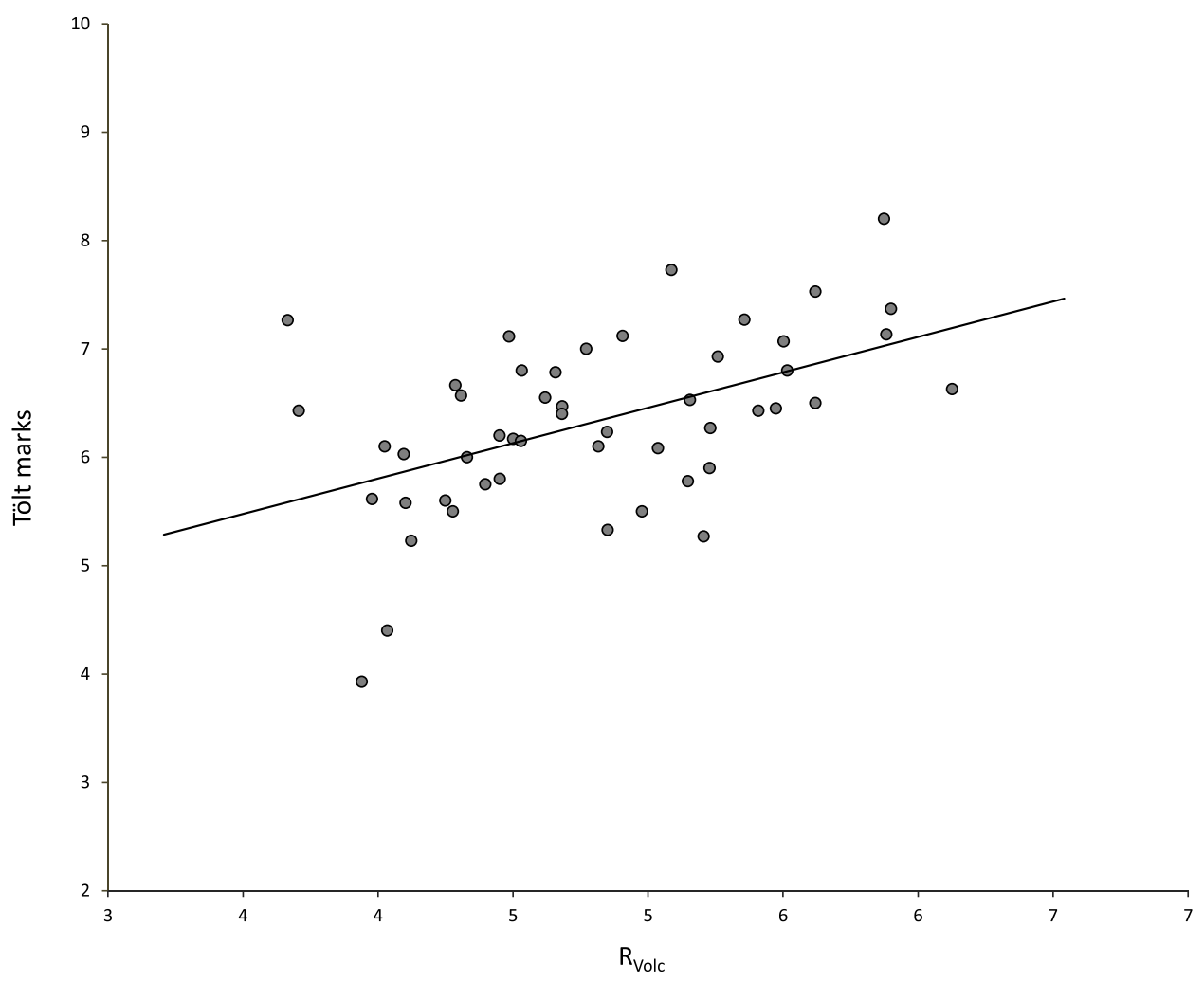

Fig. 4. Correlations of tölt marks with the ratio of the volume coefficient of the hoof capsule to the volume coefficient of the distal phalanx $\left(R_{\mathrm{Volc}}\right)$ of the left front hoof $(n=50$; $\left.r^{2}=0.24\right)$.

(Holroyd et al., 2013; Oosterlinck et al., 2015). In the present study, hoof capsule deformities such as uneven height of quarter walls and toe flares, and a backward-broken HPA were positively associated with $\mathrm{L}_{\mathrm{DHW}}$ (Table 3 ). They occurred more frequently in the longer LF than in the shorter LH which might be due to the fact that hoof manipulations in ICE mainly affect the front hooves.
Biomechanically, larger hooves are subjected to increased joint moments during break-over as well as to larger shear and lever arm forces on uneven ground or when the hoof is not landing evenly (Weishaupt et al., 2013), possibly explaining the higher prevalence of hoof capsule deformities such as flares. 
In addition to hoof manipulation, there are various reasons for the increased occurrence of hoof deformations in the front hooves. Hoof deformities might also arise as a natural phenomenon of function (supporting vs. propulsive) and the fact that front limbs carry the majority of the BM of the horse (Waldern et al., 2009). A higher prevalence of hoof pathologies occurring in the front limbs was also found in other breeds (Łuszczyński et al., 2015). Moreover, conformational factors might also play a role such as a toe-out conformation resulting in uneven quarter walls (O'Grady and Castelijns, 2011; O'Grady and Poupard, 2003; Parks, 2011). The general occurrence of hoof problems and their location is probably also dependent on breed and use (Łuszczyński et al., 2015).

Overall, the studied ICE were rather uniform in terms of conformation and showed a small range in $\mathrm{L}_{\mathrm{DHW}}$. A study population of horses with a broader range in $\mathrm{L}_{\mathrm{DHW}}$ and conformational parameters might reveal more correlations between $\mathrm{L}_{\mathrm{DHW}}$ and different hoof pathologies.

Tölt scores were positively correlated with both $\mathrm{L}_{\mathrm{DHW}}$ (Fig. 3) and $\mathrm{R}_{\mathrm{Volc}}$ (Fig. 4). Improvements of performance through shoeing manipulation are not unique in ICE, and are also practiced in other disciplines, i.e. Tennessee Walkers, Western Pleasure (Underwood et al., 2016) or Dressage horses (Clayton, 1990). It is the duty of the equestrian community to critically question performance enhancing methods if these are potentially detrimental to wellbeing and to find the ideal trade-off to combine both purposes.

\section{Conclusions}

Overall, measurements were in accordance with published values, but showed some deviations from an ideal hoof balance (backward broken HPA, imbalanced P3, long $\mathrm{L}_{\text {Balance }}$ ). However, it remains open to the extent to which these imbalances were caused by manipulation of the hoof or conformation. This study showed that certain structural deformities of the hoof were associated with a longer $\mathrm{L}_{\mathrm{DHW}}$, which should therefore be strictly regulated. In view of these findings, it is reassuring that the FEIF adapted the regulations for forelimb $\mathrm{L}_{\mathrm{DHW}}$ of ICE in competition to a maximum of $90 \mathrm{~mm}$ with exception of horses of $1.45 \mathrm{~m}$ and taller, which are allowed to have a $\mathrm{L}_{\mathrm{DHW}}$ of $95 \mathrm{~mm}$ (International Federation of Icelandic Horse Associations, 2020).

\section{Conflict of interest statement}

None of the authors has any financial or personal relationship that could inappropriately influence or bias the content of the paper.

\section{Acknowledgements}

This study was supported by the International Federation of Icelandic horse associations (FEIF), the Foundation Haldimann, the Foundation Temperatio, the Federal Food Safety and Veterinary Office (FSVO), the Islandpferde-Vereinigung Schweiz (IPV CH) and the Foundation Pro Pferd. The authors wish to thank all the owners, who kindly allowed their precious horses to be studied.

\section{Appendix A. Supplementary data}

Supplementary material related to this article can be found, in the online version, at doi:https://doi.org/10.1016/j. tvjl.2020.105462.

\section{References}

Back, W., Pille, F. (Eds.), 2013. The Role of the Hoof and Shoeing. W.B. Saunders Co., Philadelphia, pp. 147-174.
Balch, O., White, K., Butler, D., 1991. Factors involved in the balancing of equine hooves. Journal of the American Veterinary Medical Association 198, 19801989.

Balch, O., Butler, D., White, K., Metcalf, S., 1995. Hoof balance and lameness improper toe length, hoof angle, and mediolateral balance. Compendium on Continuing Education for the Practicing Veterinarian 17, 1275-1294.

Barrey, E., 1990. Investigation of the vertical hoof force distribution in the equine forelimb with an instrumented horseboot. Equine Veterinary Journal Supplement 9, 35-38.

Butler, J.A., Colles, C.M., Dyson, S.J., Kold, S.E., Poulos, P.W., 2008. Clinical Radiology of the Horse, 3rd ed. Blackwell Science, Oxford, UK, pp. 53-188.

Clayton, H.M., 1990. The effect of an acute hoof wall angulation on the stride kinematics of trotting horses. Equine Veterinary Journal Supplement 9, 86-90.

Eliashar, E., McGuigan, M.P., Wilson, A.M., 2004. Relationship of foot conformation and force applied to the navicular bone of sound horses at the trot. Equine Veterinary Journal 36, 431-435.

Feldmann, A.K., Rostock, A., 1986. Islandpferde Reitlehre. Thenée Druck AG, Bonn, Germany, pp. 262-264.

Floyd, A., Mansmann, R., 2007. Equine Podiatry, Elsevier, 1st ed. Elsevier Saunders, pp. 379-392.

Holroyd, K., Dixon, J.J., Mair, T., Bolas, N., Bolt, D.M., David, F., Weller, R., 2013. Variation in foot conformation in lame horses with different foot lesions. The Veterinary Journal 195, 361-365.

International Federation of Icelandic Horse Associations, 2013. FIPO 2013 - Rules for Icelandic Horse Sport Events. http://www.ipvch.ch/tl_files/ipvch/pdfs/ skreglemente/SK\%20FIPO\%202013.pdf (accessed 27 April 2020).

International Federation of Icelandic Horse Associations, 2020. General Rules and Regulations. https://www.feiffengur.com/documents/ FEIF_Rules_Regulations2020_complete.pdf (accessed 27 April 2020).

Kolstrung, R., Silmanowitz, P., Stachurska, A. (Eds.), 2004. Pielegnacja i podkuwanie kopyt koni. $1^{\text {st }}$ ed. Panstwowe Wydawnictwo Rolnicze i Lesne, Warsaw (in Polish).

Kummer, M., Lischer, C., Ohlerth, S., Vargas, J., Auer, J., 2004. Evaluation of a standardised radiographic technique of the equine hoof. Schweizer Archiv für Tierheilkunde 146, 507-514.

Kummer, M., Geyer, H., Imboden, I., Auer, J., Lischer, C., 2006. The effect of hoof trimming on radiographic measurements of the front feet of normal Warmblood horses. The Veterinary Journal 172, 58-66.

Łuszczyński, J., Pieszka, M., DurmałA, A., Pisarczyk, W., Augustyn, R., Dlugosz, B. 2015. Frequency of hoof conformation faults and disorders in horses of several breeds. Turkish Journal of Veterinary and Animal Sciences 39, 594-599.

Moleman, M., van Heel, M.C., van Weeren, P.R., Back, W., 2006. Hoof growth between two shoeing sessions leads to a substantial increase of the moment about the distal, but not the proximal, interphalangeal joint. Equine Veterinary Journal 38, $170-174$.

Moyer, W., 2003. Hoof wall defects: chronic hoof wall separations and hoof wall cracks. Veterinary Clinics of North America: Equine Practice 19, 463-477.

O'Grady, S., Castelijns, H., 2011. Sheared heels and the correlation to spontaneous quarter cracks. Equine Veterinary Education 23, 262-269.

O'Grady, S., Poupard, D., 2003. Proper physiologic horseshoeing. Veterinary Clinics of North America: Equine Practice 19, 333-351.

Oosterlinck, M., Aa, R., Van de Water, E., Pille, F., 2015. Preliminary evaluation of toeheel and mediolateral hoof balance at the walk in sound horses with toed-in hoof conformation. Journal of Equine Veterinary Science 35, 606-610.

Page, B., Hagen, T., 2002. Breakover of the hoof and its effect on stuctures and forces within the foot. Journal of Equine Veterinary Science 22, 258-264.

Parks, A., 2003. Form and function of the equine digit. Veterinary Clinics of North America: Equine Practice 19, 285-307.

Parks, A.H., 2011. Foot balance conformation and lameness, In: Ross Dyson, S.J. (Ed.), Diagnosis and Management of Lameness in the Horse. 2nd ed. Elsevier Saunders, St. Louis, pp. 282-309.

Pecha, A., Rumpler, B., Kotschwar, A., Peham, C., Licka, T., 2011. The influence of weighted heel boots on the duration and start of the stance phases of all four limbs in slow and fast tolt in the Icelandic horse. Pferdeheilkunde 27, 687-694.

Redden, R.F., 2003. Hoof capsule distortion: understanding the mechanisms as a basis for rational management. Veterinary Clinics of North America: Equine Practice 19, 443-462.

Thieme, K., Ehrle, A., Lischer, C., 2015. Radiographic measurements of the hooves of normal ponies. The Veterinary Journal 206, 332-337.

Turner, T., 1992. The use of hoof measurements for the objective assessment of hoof balance. Proceedings of the Annual Convention of the American Association of Equine Practitioners .

Underwood, P.Q., White, L.M., Walter, K.W., Hogue, D., Hirtz, L.K., 2016. Effect of a square-toe or perimeter-fit horseshoe on quality of movement and gait kinematics of the western pleasure horse. Journal of Animal Science $94397-$ 397.

Waldern, N.M., Wiestner, T., von Peinen, K., Gomez Alvarez, C.G., Roepstorff, L., Johnston, C., Meyer, H., Weishaupt, M.A., 2009. Influence of different head-neck positions on vertical ground reaction forces, linear and time parameters in the unridden horse walking and trotting on a treadmill. Equine Veterinary Journal 41, 268-273.

Waldern, N.M., Wiestner, T., Ramseier, L.C., Amport, C., Weishaupt, M.A., 2013. Effects of shoeing on limb movement and ground reaction forces in Icelandic horses at walk, tolt and trot. The Veterinary Journal 198 (Suppl. 1), e103-108.

Waldern, N.M., Kubli, V., Dittmann, M.T., Amport, C., Krieg, C., Weishaupt, M.A., 2020. Effect of shoeing conditions on hoof dimensions in Icelandic and 
Warmblood horses. The Veterinary Journal doi:http://dx.doi.org/10.1016/j. tvjl.2020.105461 In press.

Weishaupt, M.A., Waldern, N.M., Amport, C., Ramseier, L.C., Wiestner, T., 2013. Effects of shoeing on intra- and inter-limb coordination and movement consistency in Icelandic horses at walk, tolt and trot. The Veterinary Journal 198 (Suppl. 1), e109-113.

Weishaupt, M., Waldern, N., Kubli, V., Wiestner, T., 2014. Effects of shoeing on breakover forces in Icelandic horses at walk, tölt and trot. In: 9th International
Conference on Equine Exercise Physiology, Chester, UK. Equine Veterinary Journal 46 (Suppl. S46), 51.

Willemen, M.A., Savelberg, H.H., Barneveld, A., 1999. The effect of orthopaedic shoeing on the force exerted by the deep digital flexor tendon on the navicular bone in horses. Equine Veterinary Journal 31, 25-30.

Wissdorf, H., Gerhards, H., Huskamp, B., Deegen, E., 2010. Praxisorientierte Anatomie und Propädeutik des Pferdes, 3rd ed. M. and H. Schaper Verlag, Hannover pp. 385. 


\section{Danksagung}

An dieser Stelle möchte ich mich ganz herzlich bei allen Personen bedanken, die in irgendeiner Form zum Gelingen dieser Arbeit beigetragen haben, insbesondere bei:

Michael A. Weishaupt (Referent) und Nina M. Waldern, die mir für die wissenschaftliche Betreuung meiner Arbeit und die gesamte Zeit über mit Rat und Tat zur Seite standen.

Marie T. Dittmann und Thomas Wiestner für die Auswertung der statistischen Daten.

Marie T. Dittmann und Nina M. Waldern für das hervorragende Lektorat und ihre unermüdliche Ausdauer bei Fragen jeglicher Art.

Sarah Elingsund Mikkelsen, Nina M. Waldern, Michal Kjaer und Michael A. Weishaupt für den top motivierten Einsatz vor Ort.

Den Besitzern der Pferde, die trotz Turnierstress Zeit gefunden haben, unsere Studie überhaupt erst möglich zu machen.

Meinen Eltern und meiner Schwester, die mir das Studium ermöglicht haben und die immer für mich da waren.

Meinem Freund Fadri danke ich für seine moralische Unterstützung und dafür, dass er mir immer den Rücken frei hält.

Der FEIF (Federation of Icelandic horse associations), die die Studie nicht nur möglich gemacht, sondern auch unsere Empfehlungen für den Turniersport prompt umgesetzt hat. Der HaldimannStiftung, der Temperatio-Stiftung, dem BLV (Bundesamt für Lebensmittelsicherheit und Veterinärwesen) und der Stiftung Forschung für das Pferd, die dieses Projekt finanziell unterstützt haben. 


\section{Curriculum Vitae}

Vorname Name

Geburtsdatum

Geburtsort

Nationalität

Heimatort bei Schweizer/-in

09/1993 - 07/1997

09/1997-07/2006

Juni 2006

$09 / 2008-01 / 2014$

Januar 2014

$01 / 2014-06 / 2020$
Vanessa Herbrecht

17.08.1986

Dachau, Deutschland

Schweiz, deutsch

Entlebuch LU

\section{Schulausbildung}

Grundschule Forstern, Deutschland

Franz-Marc-Gymnasium, Markt Schwaben, Deutschland

\section{Höchster Schulabschluss}

Allgemeine Hochschulreife, Mathematischnaturwissenschaftlicher Zweig, Franz-Marc-Gymnasium, Markt Schwaben, Deutschland

\section{Studium}

Studium der Veterinärmedizin (Schwerpunkt Pferde), Vetsuisse-Fakultät, Universität Zürich, Schweiz

Abschlussprüfung vet. med.

Staatsexamen an der Vetsuisse-Fakultät der Universität Zürich

\section{Anfertigung der Dissertation}

unter Leitung von Prof. Dr. Michael Weishaupt, PhD, Dipl.

\section{ACVSMR}

am Departement für Pferde, Abteilung für Sportmedizin Pferd

der Vetsuisse-Fakultät Universität Zürich

Vorsteher: Prof. Dr. med. vet. Colin Schwarzwald, PhD, Dipl. ACVIM/ECEIM 


\section{Fachrelevante Anstellungen nach Abschluss des}

veterinärmedizinischen Studiums

$01 / 2014-11 / 2014$

Assistenztierärztin, Leistungszentrum für Pferde, VetsuisseFakultät Zürich, Schweiz

$12 / 2014-09 / 2015$ Assistenztierärztin, Tierarztpraxis Hofmatt, Huttwil BE, Schweiz

$10 / 2015-12 / 2017$ Assistenztierärztin, Kleintier- und Pferdepraxis im Dorf AG, Bäretswil ZH, Schweiz

$06 / 2018-11 / 2018$ Assistenztierärztin, Polyvets AG, Hasle LU, Schweiz

$12 / 2018-12 / 2020$ Assistenztierärztin, Bucher Tierarzt, Hitzkirch LU, Schweiz

$12 / 2020$ - heute Teilhaberin, Tierarztpraxis Capricorn AG, Ilanz GR, Schweiz 